\title{
ANALÝZA REALITNÍHO TRHU V ČESKÉ REPUBLICE
}

\section{ANALYSIS OF THE REAL ESTATE MARKET IN THE CZECH REPUBLIC}

\author{
Eduard Hromada \\ Faculty of Civil Engineering, CTU in Prague, Thákurova 7, 16629 Prague 6, Czech Republic, \\ eduard.hromada@fsv.cvut.cz, +4-202-435-3720
}

\begin{abstract}
Abstrakt
Příspěvek se zabývá rozborem aktuální situace na realitním trhu v České republice s využitím několika vybraných parametrů. Je analyzována struktura realitního trhu z hlediska vlastnictví, velikosti nemovitosti, energetické náročnosti budovy, lokality a dalších parametrů. Statistické výsledky byly získány s využitím softwaru EVAL, který autor příspěvku vyvijí od roku 2007. Tento software kontinuálně shromažd'uje, analyzuje a vyhodnocuje inzerované cenové nabídky nemovitostí v měsíční periodě.
\end{abstract}

\section{Klíčová slova}

Realitní trh; software EVAL; oceňování nemovitostí

\section{Abstract}

The paper deals with the description of the current situation on the real estate market in the Czech Republic using several selected parameters. The structure of the real estate market is analyzed in terms of ownership, apartment size, energy intensity of the building, location and other parameters. Statistical results were obtained using the EVAL software developed by the author since 2007. This software continually collects, analyzes and evaluates advertised real estate prices in a monthly period.

\section{Keywords}

Real estate market; software EVAL; valuation of real estate

JEL Classification R30, R21

DOI: $\underline{\text { https://doi.org/10.14311/bit.2017.01.05 }}$

Editorial information: journal Business \& IT, ISSN 2570-7434, CreativeCommons license (c) () published by CTU in Prague, 2017, http://bit.fsv.cvut.cz/

\section{Úvod}

Příspěvek se zabývá rozborem současné situace na trhu s bydlením v České republice. $\mathrm{K}$ mapování a hodnocení vývoje realitního trhu byl použit software EVAL, který kontinuálně shromažd'uje, analyzuje a vyhodnocuje inzerované cenové nabídky nemovitostí. Článek poskytuje odborné 
veřejnosti náhled na strukturu realitního trhu z několika různých hledisek. Článek se nezaměřuje na popis cenového vývoje nemovitostí v čase.

EVAL je softwarová aplikace, která systematicky shromažd'uje, analyzuje a vyhodnocuje cenové nabídky nemovitostí zveřejněné na realitních serverech. $V$ současné době záběr softwarové aplikace pokrývá a zaznamenává většinu ze všech zveřejněných realitních inzerátů na internetu $v$ České republice. Sběr informací z jednotlivých realitních serverů probíhá pravidelně automatizovaným mechanismem v periodě jednoho měsíce, a to souvisle již od roku 2007. Pro přesnější představu o objemech zaznamenaných dat, za první polovinu roku 2017 databáze softwaru obsahuje více než 750000 nových záznamů cenových nabídek prodeje nebo pronájmu bytů, rodinných domů, pozemků a komerčních nemovitostí. Tento softwarový nástroj umožňuje detailní analýzu vývoje nabídkových cen nemovitostí $v$ čase $v$ měsíční periodě, a to ve všech obcích České republiky a kategoriích nemovitostí, ve kterých jsou nemovitosti nabízeny k prodeji nebo pronájmu. [3], [4], [5]

Bylo vypracováno mnoho studií, které analyzují ceny nemovitostí, zejména pak na mezinárodní úrovni. Studie uvedená v odkazu [2] analyzuje dlouhodobý vzájemný vztah mezi kapitálem a hodnotou nemovitostí ve 30 rozvinutých a rozvíjejících se ekonomikách podle úrovně príjmů a struktury finančního trhu. Dokument [1] popisuje tvorbu databáze nemovitostí za účelem stanovení míry kapitalizace. Článek [7] popisuje metodu použití genetických fuzzy systémů pro tvorbu spolehlivých předpovědních modelů ohledně vývoje trhu s nemovitostmi. Studie [6] se zabývá tvorbou databáze obsahující hedonické charakteristiky a koeficienty ovlivňující ceny nemovitostí, kdy jsou využity informace z nedávno prodaných projektů.

\section{Statistické výsledky z analýzy realitního trhu v ČR}

\section{Vazba mezi jednotkovou tržní cenou a velikostí podlahové plochy bytu}

Existuje korelace mezi tržní prodejní cenou za metr čtvereční a velikostí podlahové plochy bytu. Nejvyšší cena se vyskytuje u malých bytových jednotek. Tato skutečnost je dána snadnější dostupností pořízení nemovitosti a širší cílovou skupinou. S růstem velikosti bytu jednotková cena klesá. Přitom se vyskytují rozdíly v závislosti na lokalitě. V regionu Praha je minimální jednotková cena dosažena pro větší podlahovou plochu bytové jednotky než v ostatních regionech České republiky. $S$ dalším růstem velikosti bytu pak jednotková cena znovu roste, zejména $z$ důvodu, že větší byty se častěji vyskytují v atraktivních lokalitách a centrech obcí a mají vyšší standard.

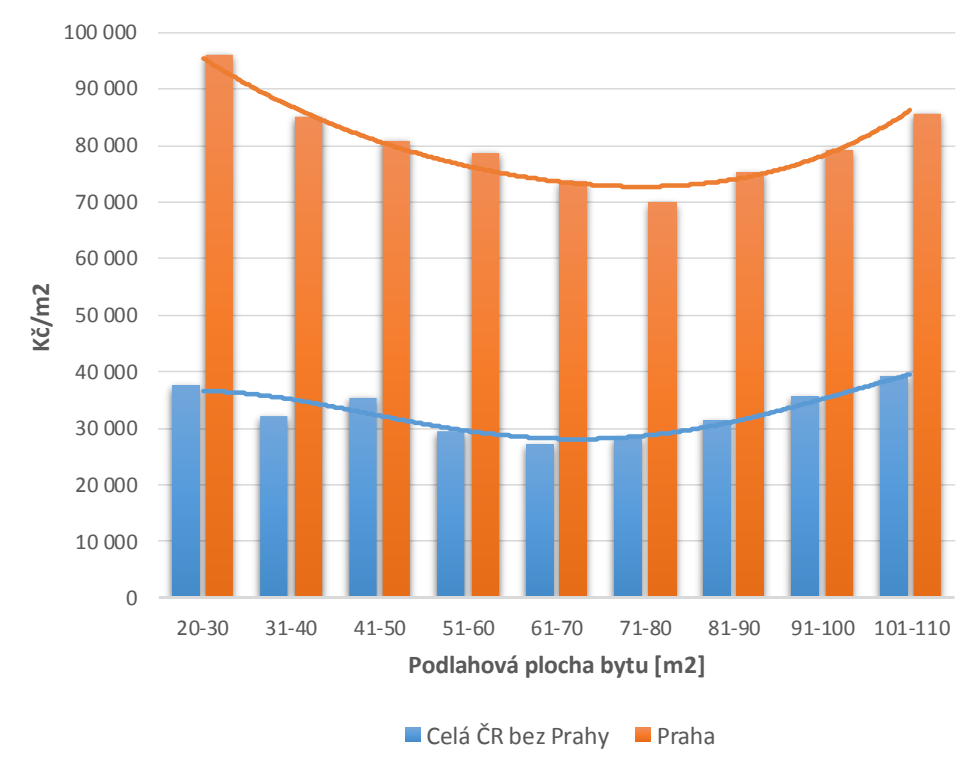

Graf 1: Vazba mezi jednotkovou tržní cenou a velikostí podlahové plochy bytu, jsou použita data ze 44 . a 45. týdne roku 2017 (zdroj: autor) 


\section{Energetická náročnost budovy}

Vyhláška č. 78/2013 Sb. o energetické náročnosti budov rozlišuje celkem 7 klasifikačních tříd energetické náročnosti budovy. Podle této vyhlášky se pro účely uvedení ukazatelů energetické náročnosti budovy $v$ informačních a reklamních materiálech při prodeji nebo pronájmu budovy nebo její ucelené části použije zjednodušená forma znázornění obsahující pouze klasifikační třídu současného stavu celkové dodané energie a její měrnou hodnotu vztaženou na energeticky vztažnou plochu. Následující graf znázorňuje strukturu nabízených bytových jednotek k prodeji v závislosti na klasifikační třídě energetické náročnosti budovy. $V$ prípadě, že nebyla uvedena žádná kategorie, Ize ve většině případů předpokládat klasifikaci: Tř́da G - Mimořádně nehospodárná.

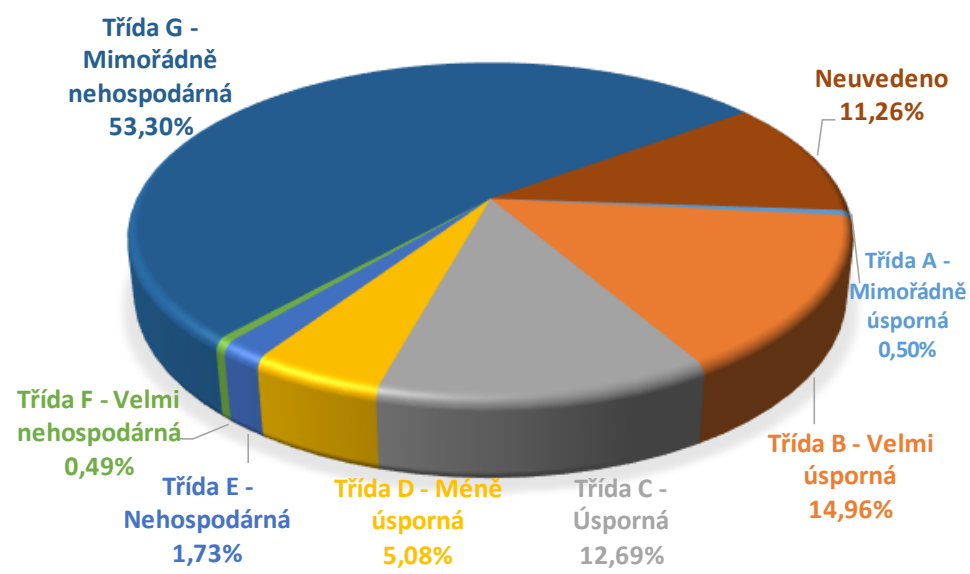

Graf 2: Energetická náročnost prodávaných bytových jednotek v České republice (zdroj: autor)

\section{Struktura cenových nabídek podle kraje - byty a rodinné domy k prodeji}

Následující dva grafy znázorňují rozložení počtu inzerátů ohledně prodeje nemovitosti podle kraje. $\checkmark$ př́padě prodeje bytů realitním obchodům výrazně dominuje region Praha. $V$ případě prodeje rodinných domů jsou nejvíce obchodovány nemovitosti ve Středočeském kraji. Naopak nejmenší počet rodinných domů mění svého majitele právě v regionu Praha. Tato skutečnost je dána zejména strukturou nemovitostního fondu, geografickými a cenovými parametry.
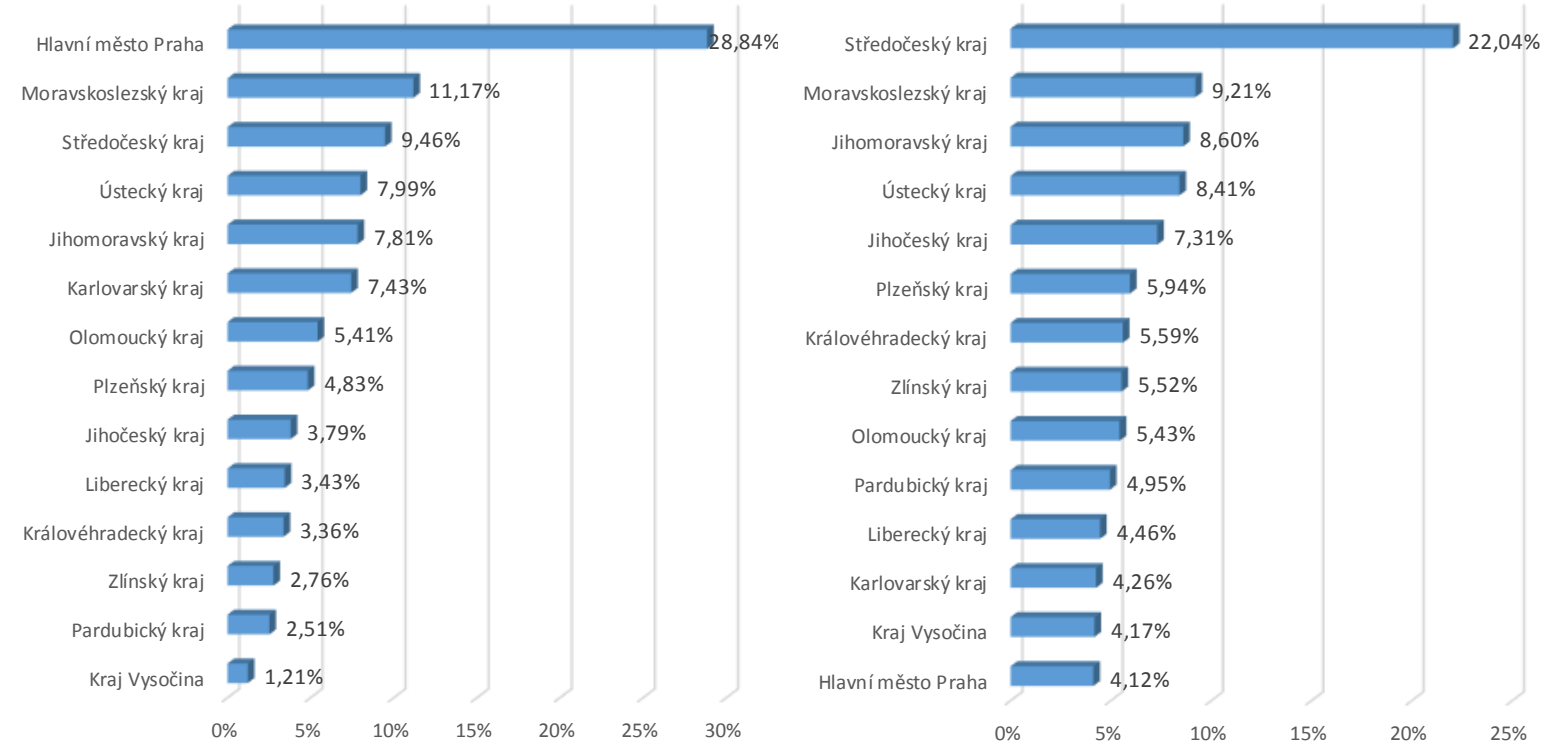

Graf 3 a 4: Struktura cenových nabídek podle kraje - počet nabídek bytů k prodeji (levý graf), počet nabídek rodinných domů k prodeji (pravý graf) (zdroj: autor) 


\section{Struktura cenových nabídek podle kraje - byty k pronájmu}

Dominantní postavení vprípadě pronájmů bytů má region Praha, Moravskoslezský kraj, Jihomoravský kraj a Ústecký kraj. V prípadě regionu Praha a Jihomoravského kraje je tato skutečnost zapřičiněna existencí velkého regionálního centra nabízejícího zejména pracovní přiležitosti a rozsáhlé služby. V případě Ústeckého a Moravskoslezského kraje se na vysokém výskytu bytů k pronájmu podílí mimo jiné mnoho faktorů, například struktura obyvatelstva, kupní síla obyvatelstva, míra nezaměstnanosti a způsob privatizace bytového fondu (např. OKD).

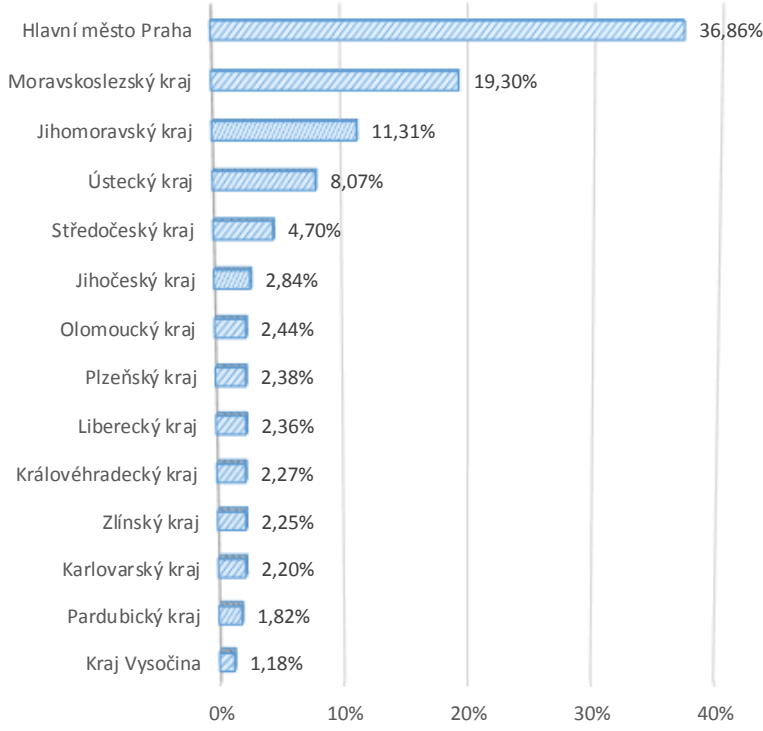

Graf 5: Struktura cenových nabídek podle kraje - počet nabídek bytů k pronájmu (zdroj: autor)

\section{Cenové rozpětí u prodeje bytů}

Následující dva grafy znázorňují počty inzerátů rozdělených do cenových intervalů, které nabízejí prodej bytu. Pro vyšší vypovídací schopnost byly vytvořeny dva histogramy, zvlášt histogram pro ČR bez regionu Praha a histogram, který obsahuje záznamy pouze z regionu Praha.
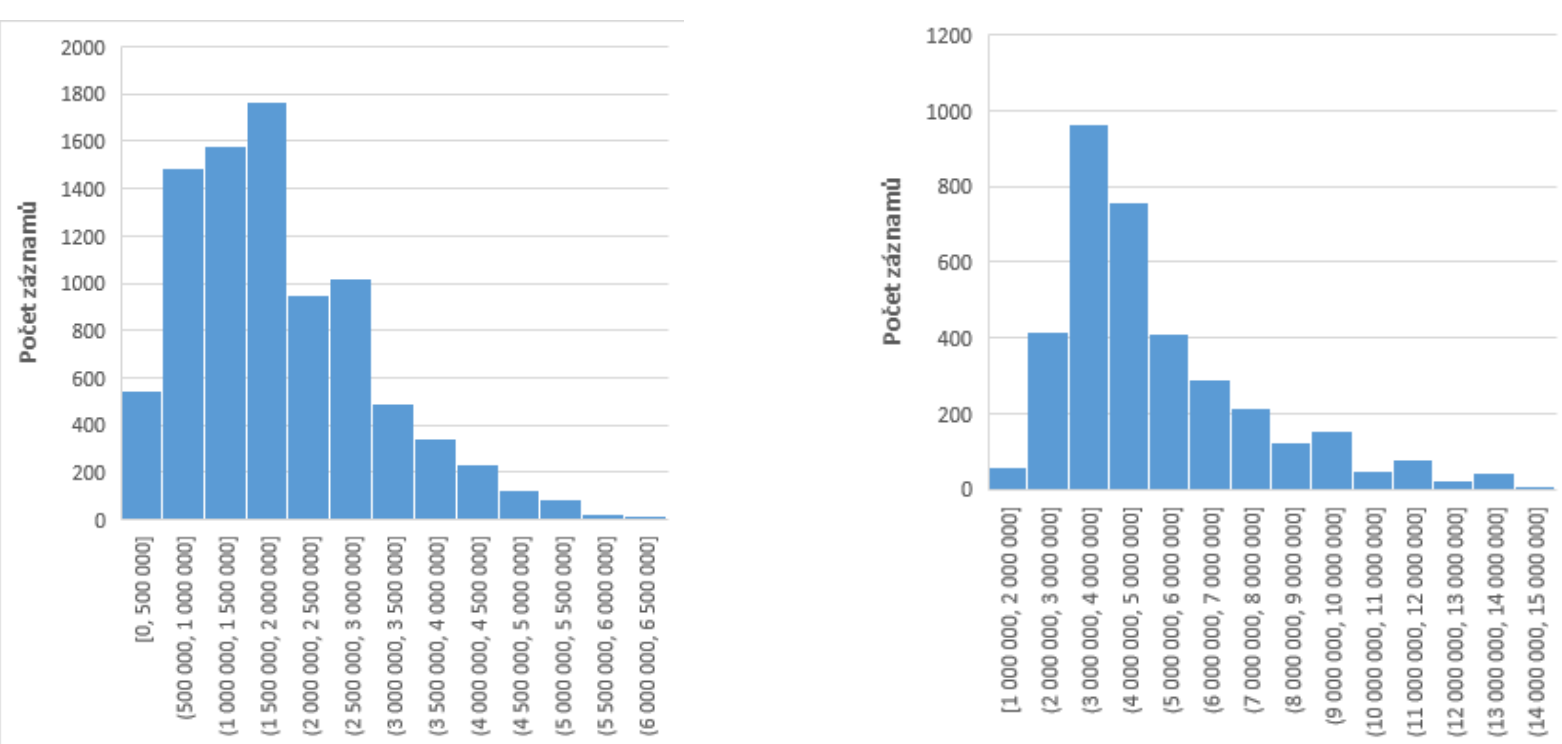

Graf 6 a 7: Cenové rozpětí u prodeje bytů - Česká republika bez Prahy (levý graf), region Praha (pravý graf), jsou použita data ze 44. a 45. týdne roku 2017 (zdroj: autor) 


\section{Další charakteristiky popisující realitní trh}

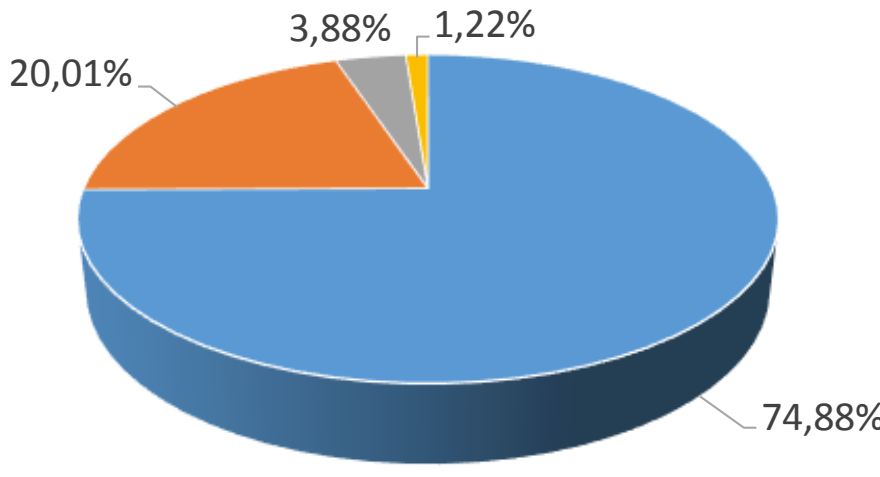

- Starší zástavba - Novostavba " Ve výstavbě - Projekt

Graf 8: Struktura bytů nabízených k prodeji z hlediska stáří nemovitosti, celá ČR (zdroj: autor)

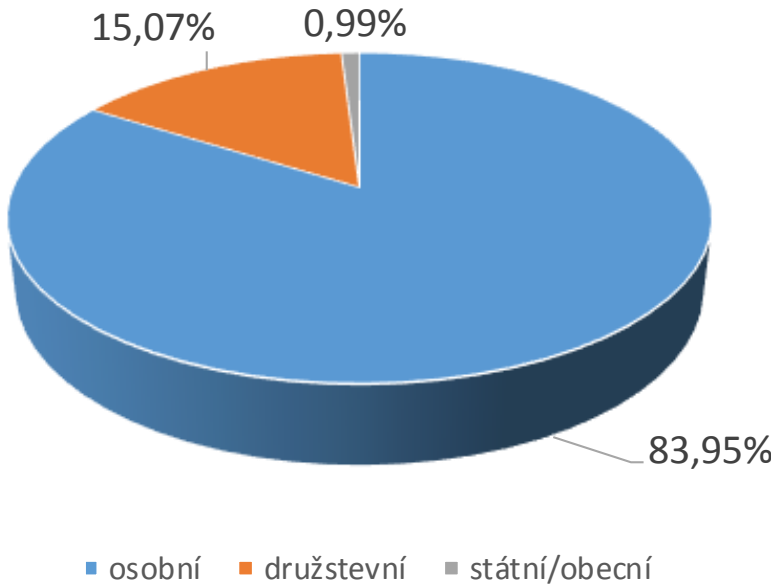

Graf 9: Struktura bytů nabízených k prodeji z hlediska druhu vlastnictví, celá ČR (zdroj: autor)

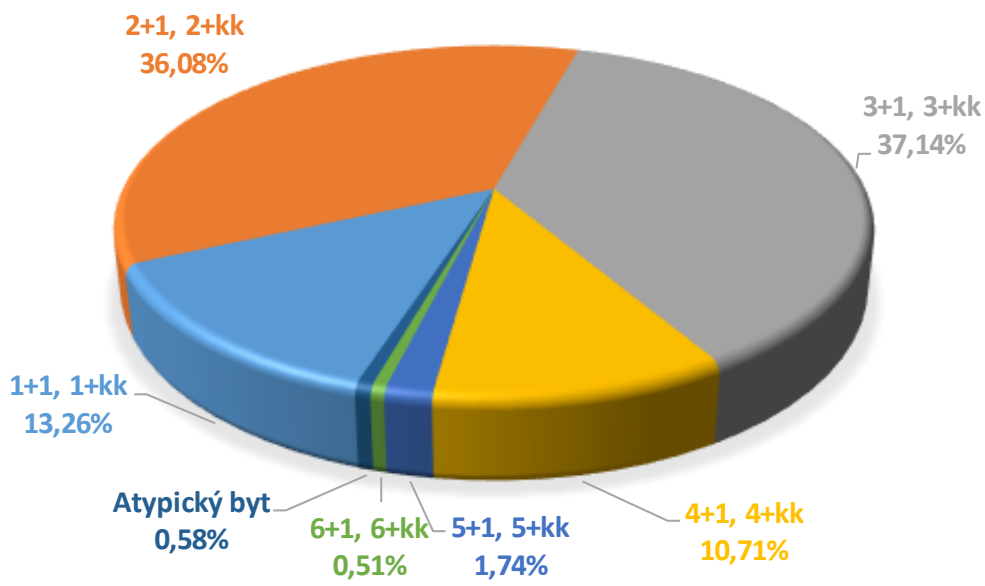

Graf 10: Struktura bytů nabízených k prodeji z hlediska kategorie bytu, celá ČR (zdroj: autor) 


\section{Poděkování}

Tento článek vznikl jako součást výzkumného projektu SGS17/121/OHK1/2T/11 Českého vysoké učení technického v Praze.

\section{Literatura}

[1] ARDIELLI, J.; JANASOVA, E. Creation of real property database for determination of capitalization rate of real estate. In: 12th International Multidisciplinary Scientific GeoConference and EXPO, SGEM 2012; Varna; Bulgaria. Volume 4, 2012, p. 877-882. https://doi.org/10.5593/sgem2012/s22.v4006

[2] ČEH ČASNI, A.; VIZEK, M. Interactions between real estate and equity markets: An investigation of linkages in developed and emerging countries. In: Finance a Uver - Czech Journal of Economics and Finance. Prague. Volume 64, Issue 2, 2014, p. 100-119. ISSN: 0015-1920.

[3] Hromada, E. (2016). Real estate valuation using data mining software. Paper presented at the Procedia Engineering, pp. 284-291. doi:10.1016/j.proeng.2016.11.621.

[4] Hromada, E. (2015). Mapping of real estate prices using data mining techniques. Paper presented at the Procedia Engineering, pp. 233-240. doi:10.1016/j.proeng.2015.10.083.

[5] Hromada, E. (2013). Decision-support tools and assessment methods. Paper presented at the CESB 2013 PRAGUE - Central Europe Towards Sustainable Building 2013: Sustainable Building and Refurbishment for Next Generations, pp. 669-672.

[6] LIU, J. G.; ZHANG, X. L; WU, W. P. Application of fuzzy neural network for real estate prediction. In: 3rd International Symposium on Neural Networks, ISNN 2006 - Advances in Neural Networks. Chengdu. China. Volume 3973 LNCS, 2006, p. 1187-1191. ISSN: 0302-9743. https://doi.org/10.1007/11760191_173

[7] TRAWIŃSKI, B.; SMȨTEK, M.; LASOTA, T.; TRAWIŃSKI, G. Evaluation of fuzzy system ensemble approach to predict from a data stream. In: 6th Asian Conference on Intelligent Information and Database Systems, ACIIDS 2014; Bangkok; Thailand. Volume 8398 LNAI, Issue PART 2, 2014, p. 137-146. ISSN: 1611-3349. 